\title{
The privilege of free movement
}

\section{Discursive representations of mobility in Finnish upper secondary level EU textbooks}

$\mathrm{T}$ his article examines how free movement and mobility are represented in Finnish upper secondary level EU textbooks. There were three such books in use at the time of writing, published in 2007, 2010 and 2014. My methodology is based on the discourse-historical approach outlined by Ruth Wodak, focusing particularly on the various discursive strategies present in the books. I have divided the groups addressed into four levels of mobility thus; 'EU movers', 'restricted EU movers', 'migrants' and 'refugees'. The EU movers were the most positively viewed group; their mobility was often related to work and studies. 'Restricted EU movers' refers to citizens of the countries that joined the EU in the twenty-first century, whose 'invasion' was allegedly feared by the older member states. Migrants outside the EU were described, inter alia, as a 'flow of millions of poor people' eager to enter Europe. Refugees, in turn, were conflated with people applying for asylum without valid grounds, creating a 'refugee flow' dealing with which member states needed to assist each other. Overall, this article concurs with the findings of previous studies: school books tend to present those moving within Europe as more agreeable, with less acceptable stereotypical characteristics being attached to extra-EU migrants and minority groups such as the Roma.

\section{Introduction}

This article analyses how EU citizens' right to free movement and migration is presented in Finnish upper secondary level EU textbooks. The topic is under-researched and also topical due to the ramifications of the Brexit process, as well as the ongoing debate on migration and asylum policies, which bring to light various approaches to different categories of migrants. In light of the current polarisation of political debates in Europe and beyond, it is important to critically assess the kinds of images of different mobile groups that are provided for students in their textbooks. Students are taught to understand that textbooks provide facts, and problematic stereotypes and hierarchical categorisations of people may have a great impact on how they think about themselves and others. The study aids an understanding of the categorisations and contradictions relating to EU citizenship and migration from a discursive perspective. Plenty of research on textbooks has been conducted before, but there are not many studies on EU textbooks. This article asks; 1) how free movement, migration and different mobile groups are described in EU textbooks and what sort of discursive methods are used in the argumentation, and 2) what sort of differences exist between Finnish-language, Swedishlanguage and vocational textbooks and how can they be explained?

The empirical material of the article includes the following three books: the vocational school book Kansalaisena 
Suomessa ja Euroopassa ('Being a Citizen in Finland and Europe', 2007), a Finnishlanguage textbook for general upper secondary schools, Kansalainen ja Eurooppa ('The Citizen and Europe', 2014), and a Swedish-language textbook for general upper secondary schools, Finlands väg till $E U$ ('Finland's Route to the EU', 2010). The books were being used in the upper secondary schools in the spring of 2017, at which time this study was started. In addition to migration, free movement within the European Union is discussed here both in terms of the right to residence and as the freedom to move across a borderless Europe, with a consideration of different views of Europeanness and otherness. It is important to examine how mobility issues are taught to students in vocational education and to Finnish-speaking and Swedishspeaking students in upper secondary schools. The books have different publication dates, but the principles of free movement were in force when all three books were published. In addition to EU citizens, another focus in the analysis is on how the books discuss third-country nationals. It is not surprising to find EU textbooks emphasising EU citizens, but my aim is also to examine whether EU textbooks include a similar differentiation between 'us' and the rest, as has been demonstrated in other textbooks (e.g. Mikander 2016). Furthermore, the article analyses differences between the three books by means of a discourse-historical approach, a variant of critical discourse analysis, focusing on the different discursive strategies utilised in describing mobility.

The sections that follow introduce the right to free movement within the European Union, previous studies on Eurocentrism, and the empirical material and research method. These sections are succeeded by four analytical sections focusing on the discourses concerning different groupings of mobile people in the three books. Finally, conclusions are drawn on the categorisations of migrants in the books.

\section{Who has the right to free movement?}

The right to free movement is a right of European Union citizens, as was already provided for workers in the founding treaty of the European Coal and Steel Community of 1951. In broad terms, free movement in the EU has evolved from an economic principle pertaining to workers into a right for all 'persons' holding EU citizenship (see also Heinikoski 2017). In other words, the free movement of labour was already a central premise of the internal market when it was launched in the 1950s; but from the 1960s onwards, the Court of Justice of the European Union (CJEU) has actively sought to turn this idea into a fundamental component of what, since 1992, has been known as European Union citizenship (Bellamy et al. 2006: 10). Free movement is also listed as a fundamental right in the Charter of Fundamental Rights adopted by the Lisbon Treaty (2007, in force since 2009).

At the same time as it has become easier for EU citizens to move around within the European Union, the countries have striven to make the entry and mobility of thirdcountry nationals - and especially refugees - more difficult, and increasingly so after the creation of the borderless Schengen Area in the 1990s. Alongside the Schengen Agreement and in order to prevent 'asylum shopping', the member states decided to establish the first Dublin Convention, requiring that an asylum application must be handled in the first country to which the applicant arrives (e.g. Guild 2006). Up to today, even resident third-country nationals do not enjoy similar rights to free movement as EU citizens do. Although the status 
of third-country nationals has already been specified in Directive 2003/109/EC and enlarged in Council Regulation 859/2003 concerning social security, third-country nationals only have the right to short-term visits prior to five years of legal residence in another EU member state (Strumia 2013: 96-9). The right to permanent residence in a member state may also be lost after six years of absence or when obtaining a permanent residence permit in another state according to Article 9 of the Council Directive 2003/109 (cf. ibid. 99). As the naturalization of immigrants is almost completely subject to national discretion, thirdcountry nationals in different member states enjoy very different rights to mobility. Furthermore, the different rights to free movement have been legitimised by the discursive categorisation of diverse mobile groups, reflecting a deliberate choice to attach certain characteristics to certain groups (e.g. Nail 2015). This means, for example, that the European Union denies that EU citizens moving in the European Union are to be seen as 'migrants', a more pejorative term reserved for third-country nationals entering the European Union (e.g. Hansen 2008). This may justly be criticised, as there is no reason why migrating EU citizens should not be termed migrants.

The right to free movement has been under debate especially during the easterly expansion of the Union during the twentyfirst century. In the enlargement, of 2004 there were fears of a rush of workers into the old member states, and the mobility of the Roma, in particular, has been the subject of a heated debate following the 2007 enlargement. It was Romania and Bulgaria who joined the Union in 2007, and the Roma populations of these two countries have been the target of special measures in other EU member states. For example, Italy decided to start collecting fingerprints from Roma in 2008, and in 2010, France expelled a large number of Roma coming in from Romania and Bulgaria (see e.g. Carrera 2014).

As stated above, the right to free movement is closely linked to the free movement area created as a result of the Schengen Agreement, which removed internal border controls between the countries which had entered into the agreement. Out of the current EU member states, the UK and Ireland have not joined the agreement, whilst Cyprus, Croatia, Bulgaria and Romania have not been yet been accepted due to allegations from other member states concerning insufficient border controls. Romania, in particular, has campaigned heavily to be accepted into the agreement, but the campaign has not yet achieved the desired result. According to the former Romanian President Traian Băsescu, the reasons for this included 'problems with the Roma', as he stated in a speech in 2010 (Băsescu 2010). Even though free movement is on paper a fundamental right of all EU citizens, in reality the opportunities of all EU citizens to move around in the Union are not equal. The differences between the privileged movers and the restricted movers are further accentuated when compared to people coming from outside the European Union.

As illustrated above, it is visible already at the legislative level that mobility rights are not the same for everyone in Europe. Refugees and poor migrants (both extraand intra-European ones) are often characterised as a burden in the European debate, such that all countries should allegedly do their share (see e.g. Kmak 2015). European mobility and communality still seem to be to a great extent based on the exclusion of others and a construction of otherness in response to an ostensible threat coming from the outside. Asylum policy 
has become stricter and in practice asylum can only be sought in the territory of a particular country. This prompts those in need of help to apply to Europe with all possible means, as a result of which they are labelled as illegal migrants or bogus asylum seekers (Kmak 2015). Such 'othering' attitudes and expressions have received more attention in recent years and this article also contributes to this debate by analysing the discourses on different groups in EU textbooks.

\section{Eurocentrism in textbooks and EU politics}

There has been plenty of research into textbooks in recent years, with more Finnish and international attention paid to the question of how European and Western identity is materialised in textbooks (see e.g. Pingel 2000; Challand 2005; Jonker 2009). Recently, Pia Mikander's doctoral dissertation studied the depiction of Westerners in Finnish textbooks (Mikander 2016). Her material includes history, social studies and geography textbooks for the school years 5-9, which is thus different from the level of books analysed here. Mikander pays attention to Eurocentrism and the presentation of Westerners as superior; Eurocentrism materialises in negative terms in such contexts, as it is being used to categorise people. For her doctoral dissertation, Inari Sakki also studied descriptions of European integration in social studies textbooks, observing that free movement is related to fears concerning criminal organisations, smuggling and illegal migration (Sakki 2010: 241).

Karim Maïche has illustrated how Eurocentric history textbooks have tended to be in her book Mitäs me länsimaalaiset! (2015). Anna-Kaisa Pudas's doctoral dissertation, in turn, argues that the focus of comprehensive schools should not only be on the regions near Finland and Europe, but rather on learning about other cultures
(Pudas 2015: 61). Pauli Heikkiläs article on European integration in Finnish textbooks concludes that the integration debate is rather sparse; however his material only covers the period up until 2005 (Heikkilä 2010). Significant changes have taken place after that: for example, the Eastern enlargements have contributed to an increasingly critical attitude to free movement and the social welfare of EU citizens, especially in the UK (see e.g. Heinikoski 2017).

EU free movement and migration policy has also been analysed in general terms in numerous studies, often paying attention to the differentiation between EU citizens and others. In her study, Francesca Strumia examines the differences between EU citizens and third-country nationals in free movement, as summarised already in the previous section (Strumia 2013: 96-9). In a similar vein, Magdalena Kmak illustrates how the mobility of EU citizens is supported, but migrants surpassing EU borders are almost automatically considered to be bogus asylum seekers. A person seeking asylum is often labelled as an illegal migrant calculatedly looking for a better standard of living. Kmak describes the phenomenon, in a Foucauldian way, as moral technology, where the asylum-seeker is seen as a helpless victim, whilst EU citizens are seen as economically profiting, pragmatic actors (Kmak 2015). According to EU rules, recruitment policy should privilege EU citizens, which makes it harder for third-country citizens legally to come to work in Europe.

When entering the Union, third-country nationals may also become tools of domestic and inter-state politics, as we have also seen in the aftermath of the so-called migration crisis of 2015. For example, France refused Tunisians with a temporary residence permit to enter France from Italy in 2011, which harmed the relations 
between the countries (Carrera et al. 2011). Another example is the legislative package that entered into force in Italy in 2009 (the so-called 'security package'), which cancelled the residence permits of third-country nationals who had been unemployed for six months, thus making their working conditions even more difficult (Merlino 2009: 4). Overall, the different treatment and discourses concerning third-country nationals is visible across all European societies.

\section{Research material and method}

It has been considered noteworthy in many studies related to Finnish textbooks that the Finnish publishers compete in the textbook markets. Here, I analyse upper secondary level textbooks where no competing versions were available, which means that all students that completed the course used the same books. In the general upper secondary school, the EU course (Europeanness and the European Union, $\mathrm{YH}_{4}$ ) was elective before the new national curriculum which entered into force in 2016. The old curriculum did not mention mobility at all as a subject to be studied, and mobility is not discussed as a separate topic but is instead scattered across different chapters of the books (see below). In turn, the first essential contents listed in the curriculum include 'European identity' and 'common European values', which means that the textbooks also have to describe these issues. The risk is, however, that the emphasis on identity and common values may lead to a so-called 'Euronationalism', whereby Europe and the people living therein are presented as superior to the rest of the world. In the mobility debate, an example of Euronationalism, as stated above, could be the fact that European mobility is called 'free movement', whilst mobility from outside the Union is 'migration' with a more pejorative significance. The Union also seeks to deliberately uphold this differentiation (see e.g. Hansen 2008).

Whereas the audience of the abovementioned general upper secondary level textbooks includes those students who decide to take the EU course as part of their social studies, the social studies course in vocational education is obligatory for all vocational school students. This does not, however, mean that the book was used in all courses. Furthermore, in contrast to the general upper secondary level books that only focus on EU issues, the vocational school textbook is intended for a study module on social, entrepreneurial and working life studies, one aim of which is to learn about the possibilities of societal influencing and decision-making in the European Union. The vocational textbook is intended for the obligatory social studies course, which deals with the EU issues included in the vocational studies. Mobility was not mentioned in the curriculum that was in force when the book was published. The vocational textbook focuses on practical issues such as social welfare rather than matters related to the European Union as such.

The Finnish-language general upper secondary school textbook was published by Edita (Kansalainen ja Eurooppa, Arola et al. 2014). The vocational school textbook (Kansalaisena Suomessa ja Euroopassa, Koskela and Passoja 2007) was published by WSOY, and the Swedish-language textbook was published by Söderströms (Finlands väg till EU, Laitinen et al. 2010). It should be noted that the Swedish-language textbook mainly corresponds to the book published by WSOY in 2005 entitled Suomen tie Eurooppaan ('Finland's Route to Europe'), but the Finnish-language book is no longer in use. Rather than focusing on the differences between publishers, it seems more 
worthwhile to analyse how EU issues are presented to different target groups: vocational students and Finnish-language and Swedish-language upper secondary school students who elect to take the EU course.

The Finnish-language general upper secondary book has 170 pages and includes 29 different references to a mobile group. The vocational school textbook, in turn, is 189 pages long, but includes only six references to mobility. The Swedish-language book is 128 pages long and includes 18 references related to mobility. It is hardly surprising that the EU-focused books and the more recent books discuss mobile groups more extensively, whilst the more general and older vocational textbook primarily focuses on other issues. The differences between the books can be accounted for to a large extent by the different contentspecific objectives of the vocational and upper secondary books, whilst the differences between the Finnish-language and the Swedish-language book may relate to the different publication dates (the Swedish text is based on a book originally published in 2005). The issues that are dealt with are mainly the same, but the Swedish-language book pays less attention to migration from outside the European Union.

All the books are intended for upper secondary level and can thus be assumed to deal more in depth with mobility and human rights issues than comprehensive school textbooks, on which the majority of previous research has focused (e.g. Mikander 2016). I decided to analyse the books used at the time of analysis instead of analysing book versions published in the same year, which means that the current selection results in more variety in the publication years of the examined books. It is natural that the book published in 2007 discussed different themes from a different perspective than a book published in

\section{Hermann Traub, Pixabay}

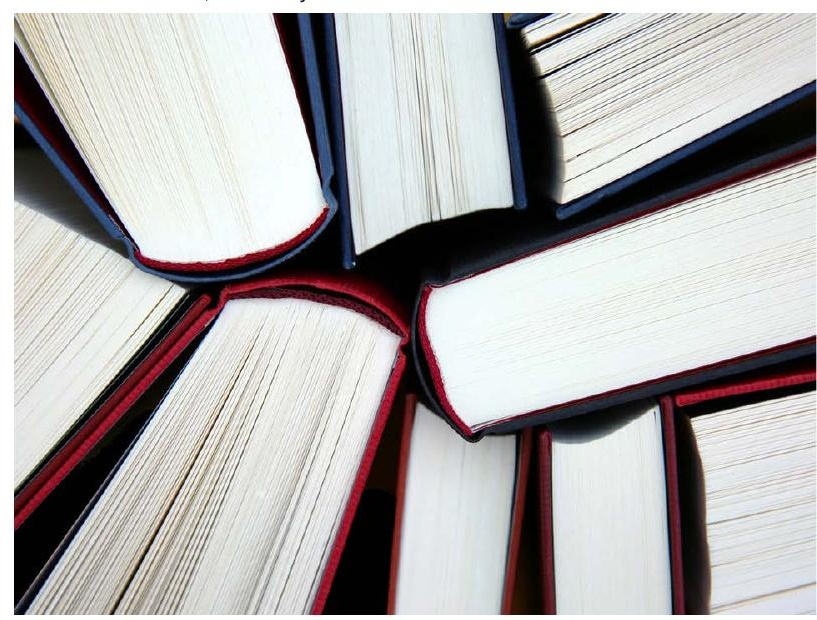

The material of the article consists of three EU textbooks utilised at Finnish upper secondary level schools.

2014, and the time perspective also adds another layer to the analysis. The selected three books were utilised in spring 2017 , thus providing an actual image of what was taught to students about EU issues at that time. In future studies, the analysis presented in this article can be complemented with an analysis of the books that have been and will be published to comply with the 2016 curriculum of the general upper secondary level textbooks. It should be noted here that all the students that started their upper secondary school before 2016 completed their studies in accordance with the old curriculum. The EU course in the new curriculum is the last obligatory social studies course, which is available at the earliest in the second year.

My method of analysis is critical discourse analysis, in particular the discoursehistorical approach developed by Ruth Wodak (2009), focusing on the representation of otherness. She divides her analysis into three areas: topics, discursive strategies and linguistic means. The topics of this study include free movement, migration and mobile groups. Different discursive strategies outlined in the discourse-historical 
approach include referential/nominal strategies, predicational strategies, argumentational strategies, perspectival strategies and intensifying/mitigating strategies (Wodak 2009: 38-44). This article makes use of the categorisation of the said strategies mainly as a tool to find references attached to different groups. It is not necessary to specify in detail which parts of the texts reflect which strategies. Different types of conceptual metaphors can be utilised as referential/nominal strategies, which are often of interest in the migration debate. Migration is sometimes metaphorically termed a flood; in such an image, the people coming from outside are being seen as potentially 'drowning' the natives (see e.g. CharterisBlack 2005: 23).

In the material, I traced the book sections related to the topics of this article and thereafter analysed what sort of discursive strategies are used to depict them. For example, I studied which types of categories are utilised to depict different groups (referential strategies), which types of characteristics are attached to different groups (predicational strategies), how arguments are justified and legitimised (argumentational strategies), how the topic is attached to other phenomena and actors (representational strategies) and whether a phenomenon or a group is emphasised or undermined (intensifying/mitigating strategies). These discursive strategies are produced by linguistic means (Wodak 2009: 38), but due to the limited space I focus more on the strategies themselves rather than on the linguistic means. The article focuses on examining how the books discuss different groups of people, how they are referred to, what sort of characteristics are attached to them and how the different groups relate to each other, as well as the argumentational strategies with which different statements are presented.
The material revealed four groups of mobile people, which are approached differently. I refer to these groups as 'free EU movers', 'restricted EU movers', 'migrants' and 'refugees'. The term 'free EU movers' refers to EU citizens' mobility within the EU, whereas 'restricted EU movers' refers to the citizens of the countries that joined the European Union in the twenty-first century and were subject to transitional restrictions. 'Migrants', in turn, refers to third-country nationals, as they are considered the only group of migrants according to the EU rhetoric. Finally, 'refugees' refers to people fleeing persecution, war or violence.

It should be noted that the issue of mobility only played a small part in the books, and comments related to mobility were scattered in different parts of the books. In the most recent Finnish-language upper secondary school textbook, EU mobility is discussed in the chapter entitled 'Citizens' Europe'. Restricted EU movers, migrants and refugees were mostly discussed in the chapters 'Regional differences' and 'Global challenges'. In the vocational school textbook, mobility is discussed under the titles 'Finnish population development' and 'EU and the EU citizen'. In the Swedish-language book, the sections discussing mobility were entitled 'Citizens' Europe' and (the) 'EU faces many challenges. The mobility of EU citizens was seen as the embodiment of a positive fundamental right, whilst challenges which were attached to mobility were spurred by regional differences, uncontrollable population growth and the threat created by 'those coming from outside' into the Union's welfare system. The following table illustrates common discursive strategies attached to different groups. Differences between the three books are not specified here, but elaborated in the analysis below. 
Table 1. Examples of the discursive strategies used in the textbooks.

\begin{tabular}{|c|c|c|c|c|}
\hline Group & Referential/nominal & Predicational & Perspectival & $\begin{array}{l}\text { Intensifying/ } \\
\text { mitigating }\end{array}$ \\
\hline Free EU movers & EU citizens & $\begin{array}{l}\text { Choosing a place } \\
\text { to live }\end{array}$ & $\begin{array}{l}\text { Searching for a better } \\
\text { job }\end{array}$ & Emphasis on work \\
\hline $\begin{array}{l}\text { Restricted } \\
\text { EU movers }\end{array}$ & $\begin{array}{l}\text { Migration flow, flow } \\
\text { of beggars, invasion, } \\
\text { rush }\end{array}$ & Masses are coming & $\begin{array}{l}\text { Fear in other EU } \\
\text { countries }\end{array}$ & Poverty emphasised \\
\hline Migrants & $\begin{array}{l}\text { Migration commu- } \\
\text { nities, flow of poor } \\
\text { people }\end{array}$ & $\begin{array}{l}\text { Living in their own } \\
\text { community, bilin- } \\
\text { gual }\end{array}$ & $\begin{array}{l}\text { Migration increases } \\
\text { racism }\end{array}$ & $\begin{array}{l}\text { Separation between } \\
\text { EU citizens and } \\
\text { others }\end{array}$ \\
\hline Refugees & $\begin{array}{l}\text { Refugee flow, } \\
\text { applying for asylum } \\
\text { without grounds }\end{array}$ & $\begin{array}{l}\text { Impetuous will to } \\
\text { come to Europe }\end{array}$ & $\begin{array}{l}\text { Fear and impossibility } \\
\text { of control }\end{array}$ & $\begin{array}{l}\text { No discussion on } \\
\text { human rights }\end{array}$ \\
\hline
\end{tabular}

I have translated all the quotations from the books into English, but I mention the original-language terms in some instances below.

\section{Free EU movers}

All three books pay most attention to the rights of EU citizens to move freely. Free movement is usually mentioned as related to EU citizenship, the Schengen Area and to the four fundamental freedoms comprising people, capital, goods and services. All the books also present the student exchange programmes of the Union and describe to a varying extent the conditions for residence. The most detailed description of the restrictions for mobile EU citizens and social welfare was found in the vocational school textbook, which also discusses the movers' family members. This is certainly related to the practical nature of the book: the aim is to inform the students about practicalities related to their everyday lives. The general upper secondary books, in turn, do not describe the mobility in practical terms but rather focus on statistics. This may be explained by the fact that the EU course in general upper secondary school aims to provide a picture of the activities of the European Union rather than to provide everyday skills for the students.

Mobility is presented as a rather pragmatic activity, in which one seeks benefits from other countries. For example, the Finnish-language upper secondary textbook from 2014 Kansalainen ja Eurooppa (hereafter KE) states that:

\section{The unemployment caused by the global financial crisis in 2008 also decreased intra-EU migratory move- ment and forced many people to return to their home countries. (KE p. 25, my italics)}

The quotation suggests that EU mobility is largely based on work and that people return to their home countries if there is no work left. Here, we can observe the very common referential strategy (Wodak 2009: 40) of referring to impersonal 'migratory movement' (muuttoliike). 'Migratory movement' is rarely used in English when referring to EU mobility, but the Finnish term seems to cover both the mobility of EU citizens and third-country nationals. The Finnish term 'muuttoliike' does not refer to a particular group of movers but may imply 
any mobile group. However, in the example below it is preceded by the predication EU, which specifies its reference.

All the books emphasise most the right to work in any country and the requirement to support oneself. It is also often stated that free movement is the most important right of EU citizens. All the books also mention that no discrimination between Union citizens may exist, for example, with regard to searching for work. EU citizens are thus presented as pragmatic actors that may select the country they wish to reside in and to return to their home countries if the circumstances change.

The Swedish-language book is the only book among the three which also emphasises studies according to which free movement is appreciated within the Union. Overall, the three books paint a very positive picture of the mobility of EU citizens. EU citizens appreciate their mobility rights, choose their place of living and thus participate in the functioning of the internal market of the European Union. It is also noteworthy that EU citizens are almost never explicitly referred to, but mobility is discussed in terms of migration or as a possibility provided by the Union. The predication 'freedom' is often attached to mobility (Wodak 2009: 42), and it is presented as a great opportunity. Mobility is presented in connection with, inter alia, working, studying, travelling and residence, and the vocational school textbook also emphasises the social welfare aspect of mobility. It should, however, be noted that the positive impacts of EU mobility are not specified in any of the books, although all of them do mention problems related to free movement such as criminality and the flow of mobile masses from the new member states, to be discussed in the following section.

\section{Restricted EU movers}

Although the books in general discussed EU citizens' right to free movement, there were people also belonging to the group of EU movers to which negative implications were attached. I call them 'restricted EU movers' and the term refers to EU citizens from the so-called 'new member states'. The transition periods concerning the citizens of the new member states were often brought up, and the fact of the enlargement was seen in terms of an obligation that the 'old member states' had towards the new ones. Enlargement thus was characterised more as a burden than as a rationally beneficial act. For example, the 2014 Finnishlanguage textbook mentioned that the mobility of Bulgarian and Romanian Roma was the subject of much debate in Europe. The section discussing Roma was contained in a one-page information box. There were at least two such boxes per chapter, including information that was not discussed in the other analysed books. The information boxes included content about topical social matters, such as Roma mobility in this case. The book states the following:
When Bulgaria and Romania joined the EU in 2007, tens of thousands of Roma may have left looking for live- lihoods from the wealthier member states. Most of them ended up as beg- gars on the streets of European cities. The beggar problem that suddenly worsened put the tolerance of many EU countries to the test. (KE p. 105, my italics)

The quotation includes many interesting discursive strategies. First of all, the representation of the text may provide the idea that it was mainly Roma who migrated from the countries, since only the Roma are mentioned, making use of an intensifying 
strategy (Wodak 2009: 42). It may be considered peculiar to state that the Roma 'may' have left to look for livelihoods; suggesting that it is uncertain how many of them actually did leave. The expression 'most of them' also raises questions since it is not specific nor justified. The ambiguous quantitative expressions were a typical feature of all the analysed books.

The quotation also raises a lot of questions, as it reinforces the image of Roma people as beggars. But what happened to those who did not end up as beggars? And how does one 'end up' as a beggar? Roma seem to be represented as pragmatic actors who were looking for livelihood. In the case of the Roma, this rationality has a negative connotation. They did not seem to be fully conscious actors, though; they had passively ended up as beggars, which in turn led to the suddenly aggravated 'beggar problem', which is a referential strategy (Wodak 2009: 40) with a negative connotation. The text does not explicate what the beggar problem means and whose problem it is.

A peculiar referential strategy is also instanced in the statement that the beggar problem put the tolerance of 'EU countries' to the test, even though countries can hardly feel tolerance. Romania and Bulgaria are also both EU countries, and it is well-known that Roma are discriminated against in these countries (see for example the European Roma Rights Centre 2012). The book also mentions that the Commission is 'planning to take action' in relation to the Roma expulsions which took place in France in summer 2010. A book published in 2014 might have been updated with the note that France nominally changed its legislation and no disciplinary actions were taken. The text also states that there was debate in Finland on whether begging should be banned by law.
Begging is presented almost as a criminal activity that poor Roma resort to and thus they do not constitute deliberate criminals, even though they are rational actors looking for a livelihood. The stereotypical image of the Roma people is strengthened by the fact that there is an image in the information box depicting a family carrying a wrecked car in a horse-drawn carriage in Romania. According to the text 'the collection and sales of recyclable items constitutes the livelihood of many Roma' (KE p. 105). Again, the text mentions 'many' Roma without tying the claim to any evidence. In reality, the collection of scrap metal seems to have declined in Romania, even though most of the paid work of the Roma in Romania is still temporary (e.g. European Union Agency for Fundamental Rights 2014).

The most recent upper secondary school book has clearly sought to incorporate current social topics, which the older books obviously do not discuss. The vocational textbook and the Swedishlanguage book mainly observe restricted EU movers from the Finnish perspective and illustrate how the flood of EU citizens was feared in Finland, but how in actual fact most migrants originated from outside the EU. The vocational school textbook Kansalaisena Suomessa ja Euroopassa (hereafter KSE) states that: Along with EU membership, Finland
became a member of a community in
which one of the basic principles is
the free movement of people from one
member state to another. A high pro-
portion of the public debate was con-
cerned with whether Finland would
be faced with a flow of migrants after
joining the EU and thus an uncontrol-
lable population increase. However, it
seems that the migratory movement 
from other member states to Finland remains minimal. Instead, there has been migratory pressure on Finland based on a higher standard of living from countries outside the EU, mainly Russia. (KSE p. 17, my italics)

In the text, migration is seen as a negative and uncontrollable phenomenon. The 'flow of migrants' and 'uncontrollable population increase' are topics on which public debate was held, according to the textbook. Such referential images (Wodak 2009: 40) reinforce the picture of migration as an impersonal phenomenon that does not concern individuals but an uncontrollable mobility. The text also assures the reader that the fear is unfounded and that the migratory movement will remain minor, utilising the impersonal term 'migratory movement' (muuttoliike). Migratory movement is a term suggesting that migration is a movement in which people involuntarily go with the flow. In the quotation, movements of EU citizens are compared with other migrations, stating that more people have come from the former Soviet Union area in search of a better quality of living and social welfare. The text uses the term 'migratory pressure', which sounds more like a term from physics than human activity. Finland is presented as an attractive country which should aim at controlling population growth, even though currently politicians seem to be worried about the decrease in population due to a low birth rate and population ageing.

The Swedish-language upper secondary school textbook Finlands väg till EU (hereafter FVE) also discusses mobility from the new member states, stating also that criminals can more easily move about in the EU area. Similar concerns as those described above related to people coming from the new member states were visible in the textbook, although the concerns mainly related to the migration of the labour force:

In many of the old EU states people have been concerned about labour migration from the new member states. In Finland, the discussion has mostly concerned the Estonian labour force. Before Estonia joined the EU, people were afraid of an invasion of Estonians into the Finnish labour market. The feared rush did not materialise, perhaps due to the reason that the old EU countries, including Finland, set a two-year transition period for the free movement of workers. (FVE p. 106, my italics)

The text makes a clear distinction between the old and the new member states with the referential strategies related to 'invasion' and 'rush' (Wodak 2009: 40). People in Finland were particularly afraid of an 'invasion' of Estonians into the Finnish labour market. Here too, migration is presented as an uncontrollable force with which Estonians would invade the Finnish labour market. The transition periods are considered to have constituted a possible reason as to why the 'rush' did not take place. In the book migration is thus presented with concepts related to uncontrollable masses, constituting an unidentified mass of people invading Finland. It is also an interesting causal argumentational strategy (ibid. 42) to state that the two-year wait would decrease the willingness of the workers to move. The countries had already applied for EU membership in the 1990s, and it is questionable whether the unrealised invasion was actually due to this twoyear additional waiting. 


\section{Migrants}

All the books also discuss migration from outside the European Union, although due to the EU emphasis, migration from outside the EU is less present in the books. It is particularly emphasised in the Finnishlanguage general upper secondary school book that the EU must control its external borders more closely due to free movement:

Those living in the EU and those who have come from elsewhere are allowed to travel freely in the Schengen Area without passport control. That is why the EU must control its external borders especially carefully. (KE p. 26, my italics)

The quotation makes a distinction between those living in the EU and those who have come from elsewhere. Free movement and the controlling of the external borders seem to have a causal relation; since people can move freely in the EU area, external borders must be controlled 'especially carefully'. Even though there do not seem to be problems in the movement of EU citizens in the Schengen Area, those who have come from elsewhere, as they are ambiguously called in the text, seem suspicious to begin with. The expression also emphasises the otherness of these people; there is the EU community and 'the rest of the world'. The actual reason for the control of the external borders seem to be that the EU wants to stop the access of unwelcome 'others' from coming to the area. People living in the EU are seen as reliable people who can move freely, whilst the control of people crossing the external borders seem necessary and natural.

The same book also discusses migrants in general and mentions Muslims as the largest religious minority in Europe. The assumption seems to be that a migrant community constitutes a separate community, that is, people from a certain country live in their own community but can communicate with the local population. A generation-long residence and bilingualism, however, appear to make their membership in the society more acceptable. An interesting argumentative strategy (Wodak 2009: 42) when comparing the approach towards intra-EU and extra-EU migration seems to be that the mobility of the EU citizens is presented without having to justify it with multi-generational residence or bilingualism. Mobility within the EU is assumed to be temporary, whilst migration from elsewhere is thought to be one way and to create new migrant communities.

As described in the previous section, the vocational textbook makes a distinction between EU movers and those coming from the former Soviet area who are allegedly searching for livelihood and social welfare in Finland. All the books present the motives of migrants as uncomplicated and only focus on the so-called 'pulling factors. Migrants are thus seen as pragmatic actors deliberating where to receive the best livelihood and social welfare. The vocational school textbook also discusses societal problems in the EU such as 'changes in family structure' which are caused by mobility. However, the book does not elaborate what this means. It can be assumed that the expression refers to the fact that people from developing countries usually have more children, but this seems rather vague. Changes in family structure, according to the book, increase the 'need to develop social policy', but the text does not explain why changes in the family structure constitute a societal problem. Is it not rather the low birth rate that is a problem in the EU countries (see e.g. Holland et al. 2011)? 
The Swedish-language book, in turn, discusses the increase in migration, which can ostensibly lead to racism:

It will be a challenge for the EU to either bring about population growth or alternatively accept a more fluent labour immigration to the EU. Reactions can be difficult to control, for example xenophobia or even increasing racism. Signs of such social problems have been visible for example in France, Italy and Austria, where extreme right political parties have cashed in on the citizens' hostility towards strangers and migrants. If the attitudes become even more entrenched, they can lead to a Fortress Europe, which closes doors for the rest of the world. (FVE p. 118, my italics)

According to the book, the EU has a problem: the primary alternative would be to bring about population growth or alternatively people should accept more fluent labour immigration into the Union. The verb 'accept' suggests that migration would be difficult to accept in the first place. The quotation also discusses the 'labour force' in impersonal terms instead of referring to actual workers. According to the causal argumentational strategy (Wodak 2009: 42) of the citation, workers' migration could incite xenophobia or racism, whereby racism is presented as an impersonal force of nature that migration can be a cause of. Then again, the structural racism of the institutions is not recognised, but racism is created in terms of people's reaction towards migration. The reason for the increase in racism, according to the textbook, would be higher migration. The victims of racism would thus be the instigators of racism, since they have moved to another country. Hostility towards migration is presented as an existing phenomenon that certain parties start to utilise. And the causal logics of the text do not end here; the more entrenched attitudes may lead to the creation of a Fortress Europe, which is closed to the rest of the world. The argumentation thus consists of a sort of circular deduction:

1. Premise: Europe needs population growth or labour immigration.

2. Premise: Labour immigration increases racism.

3. Premise: The extreme right exploits the xenophobia of citizens.

4. Premise: Xenophobia leads to Fortress Europe.

Conclusion: Labour immigration leads to Fortress Europe.

According to the argumentation, labour immigration is thus a factor that eventually may lead to Europe closing its doors to the rest of the world. As stated above, such expression denies the structural nature of racism and presents racism as a human reaction caused by immigration. None of the three books seem to present immigration from outside the EU in a very positive light, but rather as an uncontrollable force of nature leading to unmanageable consequences such as racism. With regard to EU movers, racism is not mentioned, suggesting that racism is thought to arise as a result of immigration from outside the EU.

\section{Refugees}

The most recent book under analysis here is Kansalainen ja Eurooppa, which was published in 2014. It is the only book that explicitly mentions refugees, although migrants, asylum-seekers and refugees are presented in the text simultaneously and in parallel, constituting peculiar predicational strategies (Wodak 2009: 42). In a similar 


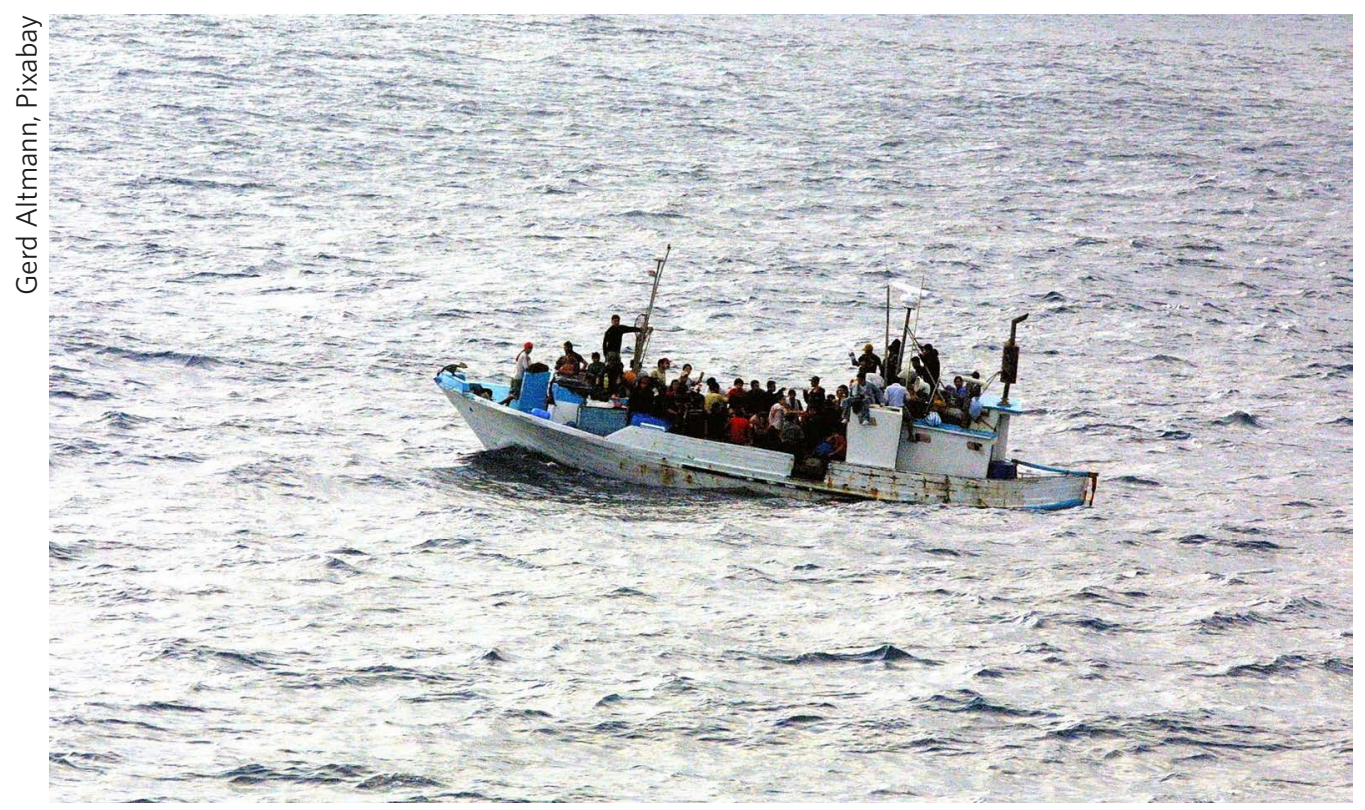

Only the most recent, 2014 book, discussed refugees.

vein to the above-mentioned Roma text, it is also a case of a one-page information box (with the title 'Fortress Europe - no entry'), discussing current societal topics. As the discussed phenomena relate to the arrival of refugees after the so-called Arab Spring of 2011, a similar discourse was not possible in the older books. The text separates migrants in accordance with how welcome they are:

On one hand, Europe requires the facilitation of immigration in the name of human rights, diversity and multiculturalism, but on the other hand, there is a fear that the flow of millions of poor people will destroy the European welfare state. ... EU countries would like to select the immigrants with a good education and language skills. ... Those seeking asylum with invalid grounds will be stopped at the border of the EU and the decisions to return them will be made in an accelerated process. ... The tightening of the migration policy of the EU has led to camps being created outside the Union's borders in Eastern Europe, Northern Africa, Turkey and Middle East, where hundreds of thousands of people have gathered, anxious to be able to move to an EU country.... Spain asked the rest of Europe for help in order to deal with the refugee flow in the shores of the Canary Islands, Italy and Malta. (KE p. 141; FVE p. 118, my italics)

The ample use of the passive voice in the text is notable, disguising as it does who demands, stops, makes the decisions to return and establishes camps. This mitigating strategy (Wodak 2009: 42) evades mentioning the actual actors of the said policies. People coming from outside the EU are presented as a mass that is anxious to move to an EU country, without mentioning that people are unlikely to stay in a refugee camp of their own free will. The same section also discusses poor migrants, asylum-seekers with invalid claims and 
refugees without explicating the differences between the groups. It is also a peculiar construction to claim that poor people would 'destroy' (romuttaa) the welfare state, assuming that poor migrants would automatically remain on social benefits and that it would destroy the system. The assumption seems to be that poverty is a fixed characteristic, making poor people dependent on the financial support of the society. The same text talks both about the flow of poor people and the flow of refugees; both groups are presented as uncontrollable forces of nature that the Union should stop before they potentially destroy the European welfare system.

The mention of good education and language skills can be questioned in the sense that the same text also discusses asylumseekers and refugees. The reader seems to be assumed to know that asylum-seekers and refugees are entitled to enter a country without such assets. The text can also be seen to suggest that most of the incomers are poor people without grounds for asylum, but who anxiously want to move to the Union. It is unclear what the authors of the text mean when they refer to the camps where people are waiting for access to Europe. If the writers mean refugee camps, it is less likely to be a case of an 'anxious' desire rather than a real need. The text categorises all migrants as people looking for better quality of living without mentioning the rights of refugees or asylum-seekers.

The increasing number of refugees is also mentioned as one of the concerns raised when Finland was considering joining the European Union (KE p. 93). Refugees thus seem to constitute a burden, but the treaty-based right to receive refugees is not mentioned, constituting an evident mitigating strategy (Wodak 2009: 43) in the refugee debate. In contrast, talk about people applying for asylum without valid grounds and impoverished migrants provides a picture that all people seeking Europe are such. It is also left unmentioned that asylum can only be sought in the territory of each country in the EU.

In contrast to the above, it should be noted that there are also neutral expressions related to refugees. The only reference to refugees in the vocational textbook is with regard to social welfare; refugees are said to have a similar right to social security as other EU citizens. In the Swedishlanguage textbook, in turn, refugees are not mentioned, not even in the glossary at the end of the book, although they are mentioned in the Finnish-language one. Overall, the concept of refugees remains very ambiguous in the EU textbooks. Then again, the issue was not in the focus of EU policy at the time of the publication of the books, nor is it mentioned in the national curriculum for the courses. Only the latest book discusses refugees, whilst the books published in 2007 and 2010 did not seem to consider the refugee debate to be significant at the EU level. The refugee issues were more frequently brought up in the EU after the so-called Arab Spring of 2011. Even the 2014 book does not seem to provide a comprehensive picture of the matter.

\section{Conclusions}

Analysis of the mobility discourses in the upper secondary school EU textbooks revealed interesting approaches. All the books had a fairly neutral approach towards EU mobility, but there were differences between diverse groups of EU citizens. For example, people are said to have been concerned about flows of migrants and workers from the new member states, who it was thought would invade the labour markets of the old member states. The mobility of Roma was also referred to as a 'beggar problem', which requires 
the exercise of tolerance on the part of the member states. Within the mobility of EU citizens, economic issues were strongly emphasised. Oftentimes, only the right to work in any EU countries was mentioned, and all the books also referred to the student exchange programmes, emphasising the positive aspects of EU mobility at the individual level.

The specification of the conditions for residence varied from one book to another, but they all made it clear that EU citizens should also be economically self-sufficient if they want to reside longer in other EU countries. The books present mobility as based on economic issues, and people are encouraged to search for better jobs in other EU countries. In contrast, people were afraid of the numbers of workers from the new member states, because they might steal jobs from the workers of the old member states. It seems that the pursuit of economic benefits by means of mobility is only encouraged for high-income people who move in small numbers rather than as part of a 'flow' (cf. Strumia 2013). Already the utilisation of the term 'movement' when describing EU migration suggests that it is temporary and constantly changing rather than permanent migration from one place to another.

The sections concerning migrants from outside the EU were revealed to be adopting categorising approaches. The vocational school textbook emphasised that there are more people coming from elsewhere than from the EU, which thus justified free movement within the EU (see also Hansen 2008); it is good for Finns to have the opportunity to leave for Europe, but people from elsewhere in Europe should not come the other way in large numbers. Then again, people coming in from Russia were presented as primarily being motivated to claim income and social welfare.
The Finnish-language upper secondary school textbook, in turn, discussed migrant communities who may have been in the country for decades and are bilingual but still constitute a separate community from the rest of the population. The Swedishlanguage book speculated on how migration seems to lead to racism and thus to the closing of borders. Migration was seen as a source of racism; migrants were thus suggested to be themselves the reason for the harsher attitudes.

Refugees were only discussed in the 2014 upper secondary school textbook, in which there was a one-page information box on the matter. The same text referred to poor people destroying the European social welfare system and to people seeking asylum without valid grounds. The book suggested that people aiming to reach Europe are poor and many of them do not even have a right to asylum. The authors did not mention human rights obligations and the fact that refugees cannot be selected on the basis of training and language skills. The authors of the older books probably did not consider the issue of refugees being intimately related to EU concerns.

In all three books, Finland and Europe are presented as attractive targets for poor people desiring to avail themselves of its comprehensive social welfare system. Migration is often presented as uncontrollable, and at the same time the ways in which different countries have been afraid of unmanageable migration is described. Migration thus appears to be a phenomenon inciting fear in both Finland and in Europe at large. It seems somewhat contradictory that the mobility of EU citizens is an activity safeguarded with the status of a fundamental right, whilst other forms of mobility are feared and sought to be controlled (Kmak 2015). Strengthening of the Union's external borders is also justified in 
relation to the internal free movement of the Schengen Area. All in all, it is questionable whether one should focus on the negative issues when describing mobility issues. In particular, migration from outside the EU is connected to a rather negative set of images. The EU is referred to as an abstract actor that tries to stop migration and select only people with education and good language skills.

There are differences between the three books, however. Perhaps the vocational school textbook provided the most positive image of mobility, but this is mainly due to the fact that mobility is the least discussed here in comparison with the other books. The vocational school textbook also includes a doubtful claim that people coming from ex-Soviet countries are seeking social welfare in Finland. The differences between the vocational school and general upper secondary school textbooks seem to be mainly related to the differences in the courses; the vocational school textbook is not intended to present the European Union in general. The approach in the Swedish-language textbook is fairly neutral, but migration from outside the EU is also presented as being a cause of racism. The Finnish-language general upper secondary school textbook includes the most extensive discussion on migration, but also presents the most stereotypical comments on both the 'beggar problem' and on the 'refugee flow'.

When seen from the perspective of previous research, what has been stated above reinforces the findings that textbooks make a distinction between 'us' and the rest of the world. Otherness can also be found inside Europe in the books, as the mobility of citizens from new member states and of the Roma has been an area of concern due to its allegedly uncontrollable nature. It is interesting that beneficial migration is not discussed in the books; migration is rather seen as a burden in the EU context.

This study concurs with the results of previous studies of Eurocentrism and categorisation between EU citizens and other groups (e.g. Kmak 2015; Mikander 2016). Finnish upper secondary level EU textbooks can be seen to reiterate the general European discourse on Europe as an attractive place which people seek to enter by any means. From the perspective of the Union, these people often appear to be applying for asylum without valid grounds. Within the European Union, mobility seems to be favourable in principle, but large numbers or the wrong kinds of EU movers appears to raise doubts about the beneficial nature of mobility.

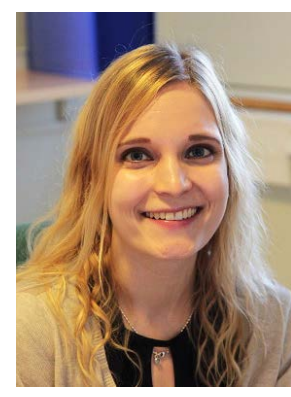

Saila Heinikoski works as a Postdoctoral Researcher at the Academy of Finland funded (funding decision number 312154) Centre of Excellence in Law, Identity and the European Narratives at the University of Helsinki. Her research interests include free movement and migration policies at the European Union, European integration as well as political discourses. She has published numerous articles in journals such as New Perspectives, Journal of Ethnopolitics and Minority Issues in Europe and Nordic Journal of Migration Research, and her monograph The History and Politics of Free Movement within the European Union: European Borders of Justice will be published by Bloomsbury in 2020.

\section{References}

Arola, Pauli, Vuokko Aromaa, Seppo Hentilä, and Sirkka Kauppinen, 2014. Kansalainen ja Eurooppa (Helsinki, Edita)

Băsescu, Traian, 2010. 'Discursul la seminarul cu tematica "Europa Centrală Centrul Europei?” Speech held at Băile Tuşnad, 24.7.2010, Presidentele României, $\quad<$ http://www.old.presidency. 
ro/?_RID =det \&tb $=$ date $\&$ id $=12317 \&$ _ PRID $=$ ag $>$ (accessed 26.8.2019)

Bellamy, Richard, Dario Castiglione, and Jo Shaw, 2006. 'Introduction: from national to transnational citizenship', Making European Citizens: Civic Inclusion in a Transnational Context, ed. Richard Bellamy, Dario Castiglione, and Jo Shaw (Basingstoke, Palgrave Macmillan), pp. 1-30

Carrera, Sergio, 2014. 'The framing of the Roma as abnormal EU citizens: assessing European politics on Roma evictions and expulsions in France, The Reconceptualization of European Union Citizenship, ed. Elspeth Guild, Cristina J. Gortázar Rotaeche, and Theodora Kostakoupoulou (Leiden, Brill), pp. 33-64

Carrera, Sergio, Elspeth Guild, Massimo Merlino, and Joanna Parkin, 2011. 'A race against solidarity: the Schengen regime and the Franco-Italian affair', CESP Liberty and Security in Europe Research Paper, <https:// www.ceps.eu/ceps-publications/raceagainst-solidarity-schengen-regime-andfranco-italian-affair/> (accessed 31.5.2019)

Challand, Benoît, 2005. 'European identity and external others (1950-2005)', Journal of Educational Media, Memory, and Society, 1(2), pp. 60-96

Charteris-Black, Jonathan, 2005. Politicians and Rhetoric: The Persuasive Power of Metaphor (Basingstoke, Palgrave Macmillan)

European Roma Rights Center, 2012. 'Factsheet: Roma rights in jeopardy', European Roma Rights Centre, 16.2.2012, <http://www.errc. org/press-releases/factsheet-roma-rightsin-jeopardy $>$ (accessed 31.5.2019)

European Union Agency for Fundamental Rights, 2014. Poverty and Employment: The Situation of Roma in 11 EU Member States. Roma Survey: Data in Focus (Vienna, European Union Agency for Fundamental Rights), <https://fra.europa.eu/sites/ default/files/fra_uploads/fra-2014-romasurvey-dif-employment-1_en.pdf>

Guild, Elspeth, 2006. 'The Europeanisation of Europe's asylum policy', International Journal of Refugee Law, 18(3-4), pp. 630-51

Hansen, Peo, 2008. EU:s migrationspolitik under 50 år. Ett integrerat perspektiv på en motsägelsefull utveckling (Malmö, Studentlitteratur)

Heikkilä, Pauli, 2010. 'Euroopan yhdentyminen suomalaisissa oppikirjoissa', Kasvatus \& Aika, 4(3), pp. 23-36

Heinikoski, Saila, 2017. European Borders of Justice: Practical Reasoning on Free Movement within the European Union, Annales Universitatis Turkuensis, B 441 (University of Turku)

Holland, Dawn, Tatiana Fic, Ana Rincon-Aznar, Lucy Stokes, and Paweł Paluchowski, 2011. 'Labour mobility within the EU: the impact of enlargement and the functioning of the transitional arrangements', NIESR Discussion Paper, 379 (London, National Institute of Economic and Social Research), <http:// www.niesr.ac.uk/sites/default/files/publications/050811_152043.pdf> (accessed 31.5.2019)

Jonker, Gerdien, 2009. 'Naming the West: productions of Europe in and beyond textbooks', Journal of Educational Media, Memory, and Society, 1(2), pp. 34-59

Kmak, Magdalena, 2015. 'Between citizen and bogus asylum seeker: management of migration in the EU through technology of morality', Social Identities, 21(4), pp. 395-409

Koskela, Mirjam, and Soile Passoja, 2007. Kansalaisena Suomessa ja Euroopassa (Porvoo, WSOY Oppimateriaalit)

Laitinen, Kari, Jarmo Rinne, Petteri Suominen, and Ragne Kommonen, 2010. Finlands väg till EU (Helsingfors, Söderströms)

Maïche, Karim, 2015. Mitäs me länsimaalaiset! Suomi ja lännen käsite (Helsinki, Into)

Merlino, Massimo, 2009. 'The Italian (in)security package: security vs. rule of law and fundamental rights in the EU, CEPS Challenge Research Paper, 14 (March 2009), <https://www.ceps.eu/wp-content/ uploads/2009/08/1809.pdf> (accessed 31.5.2019)

Mikander, Pia, 2016. Westerners and Others in Finnish School Textbooks (University of Helsinki)

Nail, Thomas, 2015. The Figure of the Migrant (Stanford University Press)

Pingel, Falk, 2000. The European Home: Representations of 2oth Century Europe in History Textbooks (Strasbourg, Council of Europe Publishing)

Pudas, Anna-Kaisa, 2015. A Moral Responsibility or an Extra Burden? A Study on Global Education as Part of Finnish Basic Education (University of Oulu) 
Strumia, Francesca, 2013. Supranational Citizenship and the Challenge of Diversity: Immigrants, Citizens, and Member States in the EU (Leiden, Brill)

Wodak, Ruth, 2009. The Discourse of Politics in Action: Politics as Usual (New York, Palgrave Macmillan) 